\title{
NON-INSTITUTIONAL CENTRES FOR SOCIAL SERVICES IN THE REPUBLIC OF MACEDONIA (WITH SPECIAL FOCUS ON THE DEPARTMENT FOR ORGANIZED LIVING SUPPORT IN THE COMMUNITY OF PEOPLE WITH INTELLECTUAL DISABILITIES)
}

\author{
ANDON DAMOVSKI \\ Department for Organized Living Support in the Local Community, Skopje, Republic of Macedonia, \\ contact: andon_damovski@hotmail.com
}

Received: 21.7.2016.

Professional paper Accepted: 18.12.2016.

UDK: 364 (497.7)

\begin{abstract}
The increased importance of the so-called relational and strategic model of social activity in social work, as opposed to previous medical models, provide a transparent promotion of the rights of people with disabilities and of their inclusion in the society. In the frame of this model, the concept of sustained housing of people with disabilities is considered as an alternative to the institutional form of care-taking and may be critical for accomplishing social inclusion for at-risk groups. This social policy approach essentially promotes the human rights of people with disabilities, suggesting they should have the opportunity to attain their goals, to make their own choices, to acquire new skills, to develop relationships with other people, and to get adequate support from skilled professionals in fulfilment of their individual needs in their living environment.

In this paper, an analysis of the non-institutional centres that provide social services in the Republic of Macedonia has been made, with particular focus on the Department for Organized Living Support in the community of people with intellectual disabilities.
\end{abstract}

Key words: social protection, non-institutional centres, social services, intellectual disability.

\section{INTRODUCTION}

Until now, persons with disabilities in the Republic of Macedonia were accommodated in institutions, which made them dependent, caused them to lose control over their personal lives, and led to their social exclusion. Respecting numerous international documents, the Republic of Macedonia has undertaken a commitment to introduce innovations in the area of social services by making reforms of the system of social protection. According to the Social Protection Act, the main changes are directed towards the development of alternative forms of protection of vulnerable groups of people with disabilities, children without families and parental care, and the elderly. For this purpose, the Ministry of Labor and Social Policy has undertaken action for the process of deinstitu- tionalization, and in this regard, a Memorandum of Cooperation between the Ministry of Labour and Social Policy, UNICEF and the World Health Organization (WHO) has been ratified, according to which there will be no admission of new users in institutions of social protection. As a result, living with support is one of the new forms of social protection in the Republic of Macedonia; this enables adults with intellectual disabilities to move out of the institutions in which they lived and become integrated into their communities, while receiving appropriate assistance and support from experts.

\section{TRENDS IN SOCIAL PROTECTION}

The system of social protection is crucial for the provision of the social security and welfare of the citizens in every country. In many developed 
and rich countries, social protection has achieved many significant results. For most European citizens, such protection is considered a great success and benefit, but this context also comes down to the following well-known argument, which may not always be correct, describing the left/right political dichotomy "The left side permanently suspects the right side that it wants to extinguish the power of social protection, seeking to liberate enterprises from major duties and to strengthen the financial power at the expense of funds intended for social protection." The complexity of social security systems imposes their constant improvement and reform. It may be concluded that the history of social security systems is a history of constant change, reforms, and progress (Ruzin, 2006).

In the context of national legislation, since its independence, the Republic of Macedonia inherited a social system based on centralization, the dominant role of the state as a provider of protection, and insignificant participation of the non-governmental, private, and religious sectors in the realm of social protection. Within that system, social welfare largely realized itself through cash transfers and benefits for citizens exposed to social risk (Damovski 2014). Social services, as nonfinancial measures whose purpose is to improve the social functioning of individuals and groups exposed to social risk, were underdeveloped and a part of the institutional forms of protection. For these reasons, many changes were made not only in legislation, but also to ways of financing, administrating, and offering social services. This social reform was based on several new principles for social protection designed to adapt the Macedonian system to European and international standards. The fundamental principles are decentralization, inclusion, pluralism, and deinstitutionalization, and the goal has been to modernize the system and politics in this area through social protection reforms.

In this regard, the system of social protection has increased the number of non-institutional services such as day care and temporary care, improved the care of children in foster families, strengthened the ability of biological families to care for their members, and provided organized living in housing units with support, small group homes, and other forms according to the needs of users in the community. Social services ${ }^{1}$ in the community are oriented toward assistance in meeting the non-financial needs and smooth realization of developmental and socializing tasks. They are also variously called personal social services, human social services, or social care services, because meeting the financial needs of vulnerable groups is essential for their security, but it does not necessarily ensure a satisfactory level of social functioning. While the different forms of financial assistance have been historically delegated to the public social security net, social services are provided by both public and private (profit and non-profit) organizations.

In the modern practice of social work, most of the services crossbreed; hence, it is difficult to separate the dominant activity or the dominant environment in which services are delivered. For example, in the local community, a day-care centre for people with disabilities (service in the local community) which at the same time conducts home visits and home care (service at home) can be established. Or, within nursing homes (institutional service), day-care centres or clubs are often open daily and have visitors who are "non-institutionalized" elderly community members (local community service), while, for example, they also take emergency calls that require intervention and house help for elderly people (service at home). In all these centres or facilities, the employees are usually experts from different fields (social workers, special education teachers, doctors, pedagogues, psychologists), each of whom has their own role in promoting the social well-being of service users. Therefore, it is sometimes difficult to determine the dominant activity performed. On the other hand, the analysis of the best practices in the area of social services in different countries implies a huge variety of social services (Bornarova, 2004).

At the same time, establishing multi-sector cooperation for the provision of social services is of great importance. Cross-sector cooperation is based on the premise that the state, the market, and

1 Social services include the benefits and facilities which help in education, health care, social protection and supported accommodations organized by the state to improve the lives and living conditions of children, persons with disabilities, the elderly, and the poor members of the community 
the civil society possess specific resources that can be combined in a productive way to solve complex social problems. In dealing with development problems, inter-sector cooperation is a strategy which, on one hand, optimizes the advantages of each sector, and on the other, limits the impact of their individual weaknesses. Partnerships with non-governmental subjects can help to increase the number of available social services and to improve the quality through competition, as well as to stimulate increased participation of the public and to create diverse programs for social help (Damovski, 2015).

Today, the promotion of multi-sector partnerships in Republic of Macedonia is implemented through activities aimed at reducing the state's role in social protection (in terms of social services) and developing its primarily regulatory and supervisory functions. The focus is moving from massive institutional forms of care to alternative social services in the community. Decentralization, deinstitutionalization, and plurality in the delivery of social services are promoted as the guiding principles in the process of reforming the system of social protection (MLSP, 2014).

\section{NON-INSTITUTIONAL CENTRES FOR SOCIAL SERVICES FOR PEOPLE WITH INTELLECTUAL DISABILITIES}

With the Social Protection Act, The Republic of Macedonia made a significant change concerning standards for providing social services and the equal treatment of all service providers and a shift from institutional social protection to the development of local social services. As a result of this change, one of the alternative institutional forms that are now provided for people with intellectual disabilities is that of organized living support.

Organized community living support for people with intellectual disability provides adequate accommodation, technical assistance, support, and skills development that are essential for social inclusion. This service can be provided temporarily or continuously depending on the needs of the service user and in accordance with his or her interests. The main purpose is for people with intellectual disabilities to gain full independence and inclusion in the community with the help and support of social experts. The intensity of such professional help and support decreases and/or increases, depending on the autonomy of the users (Stepanoska, 2012).

Respect and the inalienability of human rights are basic principles which are embedded in all national and international documents and in the contemporary practice of social work. The principles on which the service of organized living support is based refer to the best interests of the users (providing services that are adjusted to their needs); availability of services (establishing conditions and developing services); participation, responsibility, and independence of the users in making decisions on how to meet their needs; and continuity in protecting and choosing the service.

Service-organized living support can be designed for different target groups, such as children and young people with disabilities, addicts, victims of human trafficking, etc. (Alfirev, 2007). In the Republic of Macedonia, service-organized living is provided for adults with intellectual disabilities. The intention is to include all people over 18 years. Right now, there are three facilities, two of which are in Negotino and one in Skopje, in which 81 beneficiaries are accommodated and supported by a group of professional care-workers, who support their maturation toward independent day-to-day living. Users are placed in the service based on a previously given ruling by the locally authorized Social Welfare Centre that is subsequently submitted to the Office of Housing. Their accommodation is financially supported by the Ministry of Labour and Social Policy.

The process of providing social services, the content of the activities, and the processes of service management are based on the Person-Centred Approach, which was adopted primarily as a response to the inadequate treatment of users in residential institutions and is based on the philosophy of strengthening capacities through shifting the focus towards the organization of tasks. This approach implies not only a particular methodology of work with users, but also gives recommendations for all structural elements in providing a service, such as values and principles, relations with the collective, continuous development of the staff, directly provided services, responsibility 
etc. (Chiziacescu, 2006). Given the numerous elements, this approach is based on system guidance which implies interconnectivity and functional dependence of different parts that form a whole. In the context of service delivery, we cannot talk about work with users oriented towards a person if the management philosophy does not respect its own employees, treating them as instruments for achieving set goals and objectives, rather than as human beings (Thompson, 2002: 55).

The optimal staffing of assistants consists of 13-16 assistants ${ }^{2}$ working in 7-8 residential communities on a larger territory. In terms of accommodation, 3-5 persons of different gender, age, and varying levels of disability live together in one living unit, so that the unit can be heterogeneous, much like in a family. The service for independent living supports a maximum of 35 people with intellectual disabilities who live in apartments or houses. The expert team providing support in the residential units is assembled by three coordinators ${ }^{3}$ (professionals from the social sciences in fields such as rehabilitation, social work, psychology, etc.), and one Head of the Office for Independent Living Support in the Community (Sokolovski, 2010).

Starting from the specified value framework and principles of working with people with intellectual disabilities, it can be established that the main goal of supported housing is the active role of the user, who is not a passive recipient of the service and whose life is directed and controlled by a team of experts. The emphasis is put on the beneficiary himself, who with professional help and support plans the directions of his own life, while the professionals help him to make right choices and decisions, as well as to take specific steps towards fulfilling his own life goals. The support can be provided for what is most needed, at the place where it is most needed (house/apartment / local community), at the time when it is most needed ( 24 hours a day), by the person whose support is most required (assistant / coordinator / other entity). However, it should be noted that there is a difference between providing support and prob- lem solving. The direct service provider (assistant, coordinator, or other person) help the user solve his set task or problem on his own.

\section{SOCIAL SERVICES IN THE SERVICE FOR ORGANIZED LIVING SUPPORT FOR PEOPLE WITH INTELLECTUAL DISABILITIES}

The social service of organized living with support, as a non-institutional form of social protection of people with intellectual disabilities, is provided even in situations when beneficiaries are not capable of living independently. The support is directed towards enabling users to lead an independent life, to purchase food on their own, to prepare food, to develop business activities, and to avoid undesired forms of behaviour (MLSP, 2015: 7). In the department of supported organized living, beneficiaries are provided with social services by professionals who develop new ideas for the rehabilitation of beneficiaries. The social services provided for the people with intellectual disabilities can be divided into three categories: (1) Advisory-therapeutic services; (2) Socio-educational services; and (3) Daily services in the community.
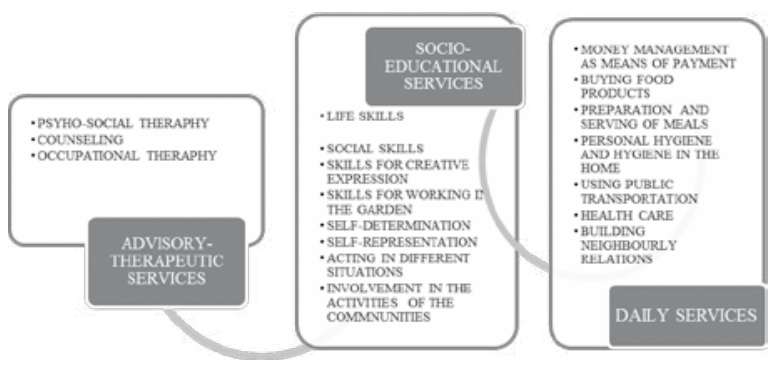

Figure 1. Network of social services in the Service for Organized Living Support

\section{Advisory-therapeutic services}

Within the provision of advisory-therapeutic services for people with intellectual disabilities, psycho-social therapy, counselling, and occupational therapy are provided.

2 The assistant gives support to the client in daily activities in the apartment and in the community in order to realize the objectives of the plan focused on the person. The assistant also provides support for the customer in accordance with the principles of active support.

3 The coordinator represents the interests of the client and is responsible to him, communicates with all services used by the client, is responsible for the programming and adoption of new skills, promotes the social inclusion and interaction of the customer, builds a natural support network for the customer, and supports the client in the selection of community resources. 
Psycho-social therapy. The new user will need time to adjust to the environment and the relationships in the group. During this period, the user is getting help to adjust and make the best of the service. The experts encourage the users in their understanding and planning activities, demonstrating a desire to help. The users that require special attention have the following needs: the need to preserve their identity, the need for security, and awareness. The specific activities that the professionals conduct concern familiarization with other users, the implementation of joint activities, becoming acquainted with the vicinity, and so on. A very important part in providing this therapy is the perception of complex life situations relevant to the service user. It is important that the professional staff assess the user's independence, his or her capacity of adaptability, and the influence of the group, all of which play an important role in his or her taking part in psycho-social therapy. These data refer to specific areas of everyday life, giving a precise picture of the user's knowledge, skills, and abilities, which together form his or her autonomy. The choice of procedures starts with the assessment and definition of the problem, continues with the definition of the objectives, the activities, and the people responsible for implementing the plan. The whole procedure is adapted to the abilities of the user. With psycho-social therapy, we allow the users to develop their skills and capabilities and to be more effective in the realization of their social tasks, but especially in improving their social relationships.

Counselling is a form of assistance aimed at the user's own advancement, personal growth, and development. Counselling aims at releasing the users from various inhibitions, offering them opportunities to get know each other better, as well as opportunities for to improve their personal and social functioning in the environment and the local community in which they live. The coordinator helps the user to mature, to overcome present and future problems more easily, focusing his or her attention on giving support for what the user is required to do for himself. He helps the user react more appropriately and be more self-confident when facing obstacles, but does not take responsibility for removing them. The goal of counselling, as part of the process of rehabilitation after insti- tutional treatment, is for the users, with the help of experts, to try to learn, feel, and understand themselves better, to experience their own feelings more clearly and make important and less important, but individual, decisions - in a word, to experience relationships in the social environment and solve problems more independently (Bratkovic, 2009).

Occupational therapy is an activity which aims to enable the users' optimal functioning in performing daily activities, in accordance with their life roles, needs, and desires. Occupational therapists include customers in activities that will increase and/or maintain their abilities, that will improve, sustain, or adapt the implementation of activities in order to enable the customers' active and independent participation in occupational therapy (Dimitrievska, 2010). The Service for Organized Living Support in the Community in Skopje is located in the suburb of Volkovo. Because of its favourable geographical position, this suburb has developed economic activity and created opportunities related to agriculture, farming, and the cultivation of vegetables and fruit. The Service for Organized Living Support, guided by the benefits offered by this settlement, started to implement an occupational therapy service for the customers as a service they receive within it. The occupational therapy conducted among users includes growing vegetables, breeding animals, and selling a street magazine. Growing vegetables as an occupational therapy provides treatment through the cultivation of vegetables (tomatoes, peppers, cucumber, potatoes, etc.) in order to achieve specific therapeutic or rehabilitation goals. The users acquire the skills of cultivating the ground, preparing the land for planting, sowing the seeds, watering the soil, transplanting the plants, and harvesting the prodc. The goal for the individual is to acquire working skills that he will further use on its own or with occasional support from an expert. This occupational therapy includes a total of 12 users that daily acquire the knowledge and skills needed for growing these crops with the help of a therapist. Breeding animals as an occupational therapy enables interaction between persons with disabilities and animals, which may help reduce stereotype movements and muscle spasms, as well as improve sensory integration, attention and concentration, 
develop self-esteem, tolerance and foster love for animals (Blatbik, Selimovic, Mujezinovic, 2012). The working group consists of 5 members. They get professional help from a therapist who is trained to work in this area. The users acquire knowledge on breeding (feeding, milking, etc.) and maintaining hygiene in the animals' environment, developing thereby a sense of responsibility. By selling a street magazine as an occupational therapy, users acquire knowledge about polite behaviour, learn how to use money, and develop their presentational and communicational skills, which facilitate their social integration. Sales usually take place with a group of users that present and sell the magazine together, with support provided by a professional. Collaborators from the area of marketing train the users how to present and sell the magazine.

\section{Socially-educational services}

Unlike the first package of services, which included advisory-therapeutic services that emphasize psycho-social and occupational therapy, the second package relates to socio-educational services, aimed at developing skills for users' personal growth and development. This group of services provided by the Service includes life skills, social skills, skills for creative expression, skills for working in the garden, self-determination, self-representation, acting in different situations, and educational activities for inclusion in the local community.

Training for life skills is directed towards imputing changes in the behaviour of users through the acquisition of certain knowledge, attitudes, and skills that will help them choose and practice healthy behaviours (Halilcevic, 2014). The training is conducted by experts (social worker, pedagogue, psychologist, special education teacher) and it is based on participatory methods of teaching and learning that makes consumers active participants in the educational process. It aims to influence the personal, emotional, and social development and the well-being of the beneficiaries, taking into account their specific needs. Various contents are processed, such as the building of self-confidence and self-conception, giving and receiving help, expressing opinions, acceptance and recognition of mistakes, respect for others, etc. Special emphasis is placed on activities that are essential for func- tioning in the apartment and/or the house and outside the home. The experts try to build the users' capacity to utilize these skills in their everyday functioning (Rojevik \& Berik, 2007).

The most general understanding of the concept of social skills is that they are very specific components of the process that allows the user to behave in a way that will be estimated as competent. A person is socially skilful when he is able to communicate with others and to exercise his rights, claims, and obligations to others Phillips (2005). Social skills training thus includes both individual and group training in verbal and nonverbal social skills. Before the users start attending the training, the experts assess their general level of social functioning. This assessment includes the users' communication skills, learning abilities, capacity to recognize and overcome differences, group social relationships (between users in the residential units and between users from other housing units and the collective). Based on the assessment of users' social skills, appropriate social skills programs are applied. Typical programs that are implemented with users refer to communicational skills, assertiveness, and stress management (Nedovic, 2011).

Training for creative expression aims to encourage creativity among users in a secure environment under expert guidance. It also helps users gain knowledge about arranging their living space. The training includes daily training for manual embroidery, manual and machine sewing, knitting, weaving, and making greeting cards, jewelry, and other decorative items. The purpose of the creative expression training is to encourage and develop aesthetic feelings and animating fine motor skills among the users. Users learn to produce creative items that they can use later on in their homes and everyday living.

Education in gaining skills for working in the garden stresses the acquisition of knowledge on maintaining hygiene in the yard area in the residential communities in which the users live, planting and cultivating flowers, using tools (e.g., hose, irrigation system) and developing a sense of nice landscaping in the courtyard area.

Self-determination training. Self-determination is actually a concept that refers to the belief that 
all people have the right to take control of their lives. It is a combination of skills, knowledge, and beliefs that allow the person to set his/her own targets and take initiative. The possibility of making decisions about one's own life is a fundamental feature of an adult. The choice and decision about a meal, the choice of place of residence, and the decision to marry are all decisions which are of great importance in the development of self-determination. Self-determination means that one has the opportunity and the ability to choose what to do as a job, how to live, how to participate and live in a group, if that is the necessary thing to achieve a set goals. Self-determination is a skill that begins to develop in early childhood, and its development lasts throughout a person's entire life. It is a process that depends on the experiences a person acquires during his or her lifetime. It should be mentioned that people who have spent their lives living in an institution have not had the opportunity to develop their self-determination skills. Today, training for self-determination helps people with intellectual disabilities to make decisions, take responsibility, and achieve greater independence.

Self-representation training aims at making a person confident to speak "for himself." Basically, self-representation refers to the making of lifestyle decisions by people with disabilities without the influence or control of others (Gorgievska, 2014). The training is guided by experts using a variety of techniques and methods combined with topics concerning everyday living. The aim is to enable users to actively participate in the protection of their rights and improve their quality of life. The experts motivate the users to present their opinion on the topics covered. The most frequently discussed topics in the Self-representation training refer to the questions about one's rights, sexual education, discrimination, stereotypes, emotions, watching television news and discussing it, and elaborating on the Convention on the Rights of People with Disabilities in an easily understandable way. The training is based on a method of group social work involving a maximum of 12 users.

Training for acting in different situations aims to help the users gain experience that everyday living requires. In the education, various topics are used such as: conflict resolution, crisis situations (asking for help in an unfamiliar situation, recognizing their own data and the data of other users of the residential community), cultural behavior and proper navigation (store, restaurant, hotel), care for their own health (changes in health, using the materials in the box - first aid, using the phone for emergencies), managing the appliances and the dangers of their improper use etc. The education is conducted in the presence of experts and assistants that use different methods in order for the users to gain life experiences.

Involvement in activities of the local community. Mostly, these educational sessions refer to the acquisition of knowledge about the location of the user in the group and socializing with people of different ages, forming natural habits of polite behaviour, using public institutions and other resources (bank, post office, pharmacy, museum etc.), forming elementary discipline and responsibility towards the environment, in order to involve users in the activities of the community (Brown \& Brown, 2003).

\section{Daily services}

The day-care services in the community provided within the Service for Organized Living Support are in close relation with the direct support that the users receive from the coordinators and nurses (assistants). This group of services includes the following:

- money management as means of payment (support for independence and the proper use of money, assistance with the purchasing of clothing, food, medicines, items, etc.);

- buying food products (acquiring knowledge about polite behaviour in stores, the procurement of necessary food products, etc.);

- preparation and serving a meal (knowledge about the proper use of place-setting (knife, fork, spoon ...), independence in serving meals, washing dishes, and maintaining place-settings, clearing away the table and gaining knowledge about activities related to cooking through direct involvement in the preparation of meals);

- maintaining personal hygiene (direct verbal support is given in order for the user to beco- 
me independent in maintaining dental hygiene and acquiring knowledge about brushing; washing hands after using the toilet, as well as before and after meals; independence in bathing and/or showering; maintaining intimate hygiene; becoming independent in choosing clothing and footwear, including independence in putting on and taking off tops, pants, socks; keeping clothes in a separate locker; dressing according to weather conditions; acquiring the habit of separating clean and dirty clothes; ironing clothes; undoing and buttoning bands, zippers, belts, etc.);

- maintaining hygiene in the home (support to ensure the acquisition of knowledge about maintaining hygiene in the home [living room, dining room, bedroom, toilet . . .], using a broom and vacuum, wiping dust, caring for the furniture and the other interior pieces, etc.);

- using public transportation (includes support for introducing the user to his or her closer and wider environment and his or her orientation in space, in order to create opportunities for the independent use of public transportation);

- health care (organization of general medical check-ups, acquiring the habits of regular health check-ups, regular prescription and use of medications for chronic therapy, and regular specialized medical [dental, neurological, gynecological ... .] check-ups);

- building neighbourly relations (introduction to the vicinity and neighbourly visits, maintaining contacts through joint informal social association, wishing others well on holidays, in order to achieve better acceptance by the neighbourhood in which the users live).

The experts in the Service for Organized Living Support collaborate with a number of institutions, organizations, and services: the Ministry of Labour and Social Policy, centres for social work, health institutions, and local authorities. For example, the professionals from the Service establish contacts with centres for social work to ensure the rights that users exercise in the centre through which they are accommodated in the Service. This includes extracting personal documentation as well as exercising rights in the area of social protection (compensation for deafness, blindness, exercising the right of a family pension, custody, etc.). The Ministry of Labour and Social Policy is a strategic partner of the Service in the process of deinstitutionalization, and for this reason, experts collaborate with some representatives of the relevant Ministry. The collaboration mostly concerns reporting changes among the users and reports monthly the activities implemented by the users. They organize various joint meetings to improve the quality of the users' lives. They have contacts with health facilities in order to care for the health and safety of the clients that receive the support and they also realize cooperation with the local community in which the Service is located. Generally, the cooperation with the local community aims at inclusion in the existing resources offered by the community. Besides the contacts with the public institutions, it is necessary for the professionals to cooperate with partners in non-profit organizations, concerning competences and certain authorizations. An example of such a cooperation is that between the Office of Housing and Food Bank ${ }^{4}$ in order to provide bakery products for consumers. The professionals, working with public institutions and organizations, form a network of cooperation. Of great importance is also the development of cooperation with public figures who can contribute by promotint the realization of a certain goal. A positive example of such cooperation is the renovation of the day-care centre in Skopje, which was financially supported by the U.S. Embassy in Skopje and Habitat. ${ }^{5}$

\section{CONCLUSION}

With the development of the relational model for protecting people with intellectual disabilities

4 The basic principles of the organization "FOOD FOR ALL - BHM" are based on the Charter of the European Federation of Food Banks (FEBA). The organization "FOOD FOR ALL - BHM", through mediation with social institutions (children without parental care, soup kitchens, centres for social work, etc.) or other organizations also help socially excluded and poor people (associations of single mothers, people with special needs, etc.).

5 Habitat For Humanity - Macedonia is a non-governmental, non-profit organization dedicated to providing simple, decent, and affordable housing solutions for those living in poverty regardless of their ethnic background, gender, or religious affiliation, thus enabling them to leave poor housing environments and improve the quality of their lives 
and in accordance with postmodern concepts in social work, new methods and forms have been developed in the planning and providing of social services. The Social Protection Act predicts the introduction of standards for providing quality social services, which creates room for ways and styles of living that are acceptable to everyone. Living with support opens a sequence of situations in which it is easy to recognize the characteristics and values of each individual. In this way, a person is given the opportunity to choose independently or with the support of an expert, who helps him make his own decisions and take responsibility. The main objective of all the activities implemented by experts in the Service is to enable users to live independently, to build their personality to the greatest extent possible, to be satisfied with what they have achieved, through various activities such as training for life skills, social skills, creative expression, self-determination, etc., which will help them acquire knowledge, skills, and attitudes needed for their everyday living.
The introduction of new standards for social services in non-institutional centres requires changing the roles of experts in order to provide social services. The specificities of providing social services in non-institutional centres require for professionals to apply extremely different roles compared to the ones applied within the provision of social services (roles of innovator, motivator, supporter, agent). Besides having certain roles in their work, they focus on the role of mediation (representing users, speaking on their behalf, monitoring the behaviour of the users, enabling users to speak for themselves, giving their own example of how to behave, communicating with all services used by the client, building a natural support network, conducting training sessions for the staff that realize certain segments of the individual plan, etc.). It is therefore necessary for professionals who are building their capacity in the provision of social services to be educated and to gain skills and techniques for working with persons with intellectual disabilities in this new context. 


\section{BIBLIOGRAPHY:}

Alfirev, M. (2007): Encouraging the development of self-determination and self-advocacy of young people with intellectual disabilities. Zagreb: Association for Promoting Inclusion.

Batshaw, L. M. (2013): Children with disabilities. Baltimore: Brookes Publishing Co.

Blatbic, S., Selimovic, S., Mujezinovis, A. (2012): Occupational therapy with animals. Annual of Social Work, Vol $19,2,241-274$.

Bornarova, S. (2004): Social services for elderly people in the modern trends of social politics - situations and perspectives in the Republic of Macedonia. Master's thesis. Faculty of Philosophy. Skopje.

Bratkovic, D. (2009): Quality of life in patients with moderate and severe mental retardation in family and institutional living conditions. Doctoral thesis. Faculty of Education and Rehabilitation Sciences in Zagreb.

Brown, I., Brown, R. I. (2003): Quality of life and disability. In: An Approach for Community Practitioners. (pp. 104-125). London and Philadelphia: Jessica Kingsley Publishers.

Chiziacescu, D. (2006): Providing social services for people with invalidity. Zagreb: Initiative for Following and Observing Invalidity.

Damovski, A. (2014): Application of the policy of conditional cash transfers in the Republic of Macedonia. Social Thought, 83/84, 89-107.

Damovski, A. (2015): Services for people with intellectual disabilities in the Republic of Macedonia: vision and reality. Journal of Social Policy, 11/2, 523-550.

Dimitrievska, V. (2010): Practices of housing among people with intellectual disabilities: community-based supported housing services. Journal of Social Policy, 6, 552-568.

Donevska, M. (2006): Social work in the local community. Skopje: Faculty of Philosophy in Skopje.

Gorgievska, S. (2014): Program for Self-Advocacy Association of SOLEM. Special Education and Rehabilitation, 4, 36-38.

Halilcevic, S. (2014): From institution into community. Voice of Self-Advocates, 13. - Association for Self-Advocacy, Zagreb.

Kubai, R. (1998): Social services decentralization and municipal politics. Chapel Hill: University of North Carolina at Chapel Hill.

Ministry of Labour and Social Policy (2014): Manual for development of social services for vulnerable groups in the local communities. Skopje: Government of the Republic of Macedonia, Ministry of Labour and Social Policy.

Ministry of Labour and Social Policy (2015): Rulebook on the requirements for standards to support the realization for organized living support in a special residential community. Skopje: Government of the Republic of Macedonia, Ministry of Labour and Social Policy.

Nedovic, G. (2011): Level of development of social skills among people with invalidity. Belgrade: Faculty of Special Education and Rehabilitation in Belgrade.

Petrov, R., Gurcinovska, L., Stanojkovska-Trajkovska, N. (2008): Protection and rehabilitation of people with invalidity. Skopje: Faculty of Philosophy in Skopje.

Philips, X. (2005): The effects of deinstitutionalisation on people with mental handicaps: University of California.

Rojevik, Z., Berik, N. (2007): School for life skills. Belgrade: Child's Heart, a humanitarian organization to assist people with disabilities.

Ruzin, N. (2006): Modern systems of social protection. Skopje: Faculty of Philosophy in Skopje.

Sokolovski, Z. (2010): Treatment of moderately mentally retarded persons. Sociological Review, 12, 100-112. 
Stepanoska, E. (2012): People with moderate and severe intellectual disability covered by the form - living with support. Master's theses. Faculty of Philosophy in Skopje.

Thompson, N. (2002): The mentally retarded people. New York: Mc Craw Nill.

\section{NEINSTITUCIONALNI CENTRI ZA SOCIJALNE USLUGE U REPUBLICI MAKEDONIJI (S POSEBNIM OSVRTOM NA ODJEL ZA PODRŠKU ORGANIZIRANOM ŽIVLJENJU U ZAJEDNICI OSOBA S INTELEKTUALNIM TEŠKOĆAMA)}

Sažetak: Sve veća važnost tzv. relacijskog $i$ strateškog modela društvenih aktivnosti u socijalnom radu, nasuprot ranijim medicinskim modelima, omogućava unapređenje prava osoba s invaliditetom i njihovo uključivanje u društvo. U okviru ovog modela koncept stambenih zajednica za osobe s invaliditetom smatra se alternativom institucionalnom obliku skrbi za ove osobe, te može imati ključnu ulogu u ostvarivanju socijalne inkluzije rizičnih društvenih skupina. Ovakav pristup u socijalnoj politici značajno unapređuje ljudska prava osoba s invaliditetom, naglašavajući potrebu da im se pruži prilika za ostvarivanje njihovih osobnih ciljeva, prilika za osobni slobodan odabir, usvajanje novih vještina, razvoj njihovih odnosa s drugima i dobivanje primjerene stručne podrške u zadovoljavanju njihovih individualnih potreba u okolini u kojoj žive. U ovom radu prikazana je analiza neinstitucionalnih centara koji pružaju socijalne usluge u Republici Makedoniji, s posebnim osvrtom na Odjel za podršku organiziranom življenju u zajednici osoba s intelektualnim teškoćama.

Ključne riječi: socijalna zaštita, neinstitucionalni centri, socijalne usluge, intelektualne teškoće 